BRITISH INSTITUTE OF ARCHAEOLOGY AT ANKARA MONOGRAPH SERIES published by B.A.R. and obtainable ONLY from B.A.R., 5 Centremead, Osney Mead, Oxford OX2 ODQ.

B.A.R.-S80, 1980 Aşvan Kale; Keban Rescue Excavations, Eastern Anatolia. I. The Hellenistic, Roman and Islamic Sites, by Stephen Mitchell. ISBN 086054091 X. 275 pp. 126 figs. 10 plates. Price $£ 14.00$.

B.A.R.-S85, 1980 Pre-Classical Pottery of Eastern Anatolia, by H. F. Russell. Monograph No. 2.

ISBN 086054098 7. OUT OF PRINT.

B.A.R.-S105, 1981 Roman Roads and Milestones of Asia Minor: Fasc. 1, by David French. Monograph No. 3.

ISBN 086054123 1. OUT OF PRINT.

B.A.R.-S135, 1982 Regional Epigraphic Catalogues of Asia Minor II: The Ankara District. The Inscriptions of North Galatia, by Stephen Mitchell with the assistance of David French and Jean Greenhalgh.

ISBN 0860541665 . OUT OF PRINT.

B.A.R.-S156, 1983 Armies and Frontiers in Roman and Byzantine Anatolia. Proceedings of a colloquium held at University College, Swansea, in April 1981, ed. Stephen Mitchell. British Institute of Archaeology at Ankara Monograph No. 5.

ISBN 0860541983 . Price $£ 16.00$ post free.

B.A.R.-S168, 1983 Taşkun Kale; Keban Rescue Excavations, Eastern Anatolia, by Anthony McNicoll. British Institute of Archaeology at Ankara Monograph No. 6.

ISBN 0860542157 . Price $£ 15.00$ post free.

B.A.R.-S261, 1985 Survey of Medieval Castles of Anatolia I: Kütahya, by Clive Foss, with plans by Robin Fursdon. British Institute of Archaeology at Ankara Monograph No. 7.

ISBN 0860543382 . Price $£ 15.00$ post free.

B.A.R.-S297, 1986 The Defence of the Roman and Byzantine East. Proceedings of a colloquium held at the University of Sheffield in April 1986, ed. P. Freeman and D. Kennedy. Monograph No. 8.

ISBN $0860543811 . £ 40.00$ post free.

\title{
Membership
}

The annual subscription to the B.I.A.A. is $£ 15.00$ per annum, for which subscribers will receive the Journal, the Annual Report and invitations to lectures. There is a student rate of subscription of $£ 2.00$, which does not include the Journal. For membership please apply to the London Secretary of the B.I.A.A., c/o The British Academy, 20-21 Cornwall Terrace, London NW1 4QP.

Payment for all publications and subscriptions should, if possible, be made in sterling by international money order or by cheque drawn on a British Bank. Payment may be made using other methods, using the current rate of exchange with $10 \%$ added to cover bank charges. 


\section{OCCASIONAL PUBLICATIONS:}

No. 1

THE STATUE OF IDRI-MI

Out of print. Photocopy available unbound $£ 22.00$.

No. 2

THE ALALAKH TABLETS

By D. J. WISEMAN

With an Appendix by O. R. G U R NEY

Out of print, but may be obtained from University Microfilms Ltd., P.O.B. 71, 18 Bedford Row, London WC1R 4EG. Or University Microfilms, P.O.B. 1548, Ann Arbor, Michigan 48106, U.S.A. Photocopy available unbound $£ 22.00$ from B.I.A.A.

No. 3

THE SULTANTEPE TABLETS, VOL. 1

By O.R. GURNEY and J. J. FINKELSTEIN

(Reprint)

Price $£ 15.00$

No. 4

ALANYA (ALA', IYYA)

Out of Print.

No. 5 THE GEOGRAPHY OF THE HITTITE EMPIRE

By JOHN GARSTANG and O. R. GURNEY

Out of print, but may be obtained from University Microfilms Ltd. For address see above. Photocopy available unbound $£ 22.00$ from B.I.A.A.

No. 6

BEY CES ULT AN, VOL. I

By SETON LLOYD and JAMES MELLAART

Price $£ 23.00$

No. 7

THE SULTANTEPE TABLETS, VOL. II

By O. R. GURNEY and P. HULIN

Price $£ 15.00$

No. 8

BE Y CESULT AN, VOL. II

By SETON LLOYD and JAMES MELLAART

Price $£ 23.00$

Nos. 9 and 10

EXCAVATIONS AT HACILAR

By JAMES MELLAART

In two volumes

Price 550.00 . 25 per cent reduction to members of the Institute. Obtainable direct from the Edinburgh University Press, 22 George Square, Edinburgh EH8 9LF.

No. 11

BEYCESULTAN, VOL. III, PART I

By SETON LLOYD

Price $£ 12.00$

ANATOLIAN STUDIES

Back numbers are obtainable at $£ 23.00$ each. $£ 17.00$ to members of the Institute

INDEX TO ANATOLIAN STUDIES

Volumes 1-10, 11-20 and $21-30 £ 4.50$ each.

A CLASSICAL MAP OF ASIA MINOR

$B y$ W. M. CALDER and GEORGE E. BEAN

Being a partial revision, by kind permission of Messrs. John Murray, of J. G. C. Anderson's Map of Asia Minor. Price $£ 2.50 ; £ 20.00$ for 10 .

TWENTY-FIVE YEARS OF BRITISH ARCHAEOLOGY IN

ANATOLIA

By SETON LLOYD

Price $£ 1.75$

Obtainable from the Publishers. Postage included. 25\% Discount to subscribers and booksellers.

The British InSTItUTE of ARCHAEOlogy at ANKaRA

c/o The British Academy, 20-21 Cornwall Terrace, London NW1 4QP

Printed in Great Britain by Stephen Austin \& Sons, Ltd., Caxton Hill, Ware Road, Hertford, Herts. 